\title{
СОЦІоКУЛЬТУРНИЙ КОНТЕКСТ ЦІННІСНОГО СВІТОВІДНОШЕННЯ ОСОБИСТОСТІ
}

\section{Т.А. Хорольська}

Сучасна епоха - це епоха трансформації старої (класичної) системи цінностей та становлення нової ціннісно-світоглядної культури людини, які раніше не вміщувались на шкалі матеріальних та чисто соціальних цінностей. Наш час- це час становлення нового історичного типу культури, який своїм епіцентром обирае людину та їі світовідношення. На будь-якому етапі становлення і розвитку особистості їі ціннісним потенціалом, фундатором та незвичним життєвим фільтром постає конкретно-історичний тип культури. Саме культура надае людині можливість здійснити свій індивідуальний життевий досвід та призвести його «до стихії всезагальності» (Гегель), до співвіднесеності 3 загальнолюдським.

Новий, посткласичний тип культури та організація соціального і індивідуального людського буття у загальнопланетарному плані потребують більш чіткого осмислення «місця людини у космосі» (Шелер) як біо-соціально-культурної істоти. Сьогодні ми повинні з розумінням підійти до явища історичної мінливості не лише способу існування людини, але й до співвідношення і1ї сутнісних сил з силами природи та культури. По іншому, зусилля системи наук про людину, людську особистість повинні бути спрямованими на формування нової ціннісносвітоглядної самосвідомості і орієнтації людини у світі взагалі і у світі культури зокрема. Осереддям нового світовідношення людини до світу, суспільства, культури, до себе самої може стати усвідомлення того, що від «кінця світу», що нібито насувається, людину не врятує ніхто, крім неї самої. Інакше кажучи, людина повинна зрозуміти, що вона не $\epsilon$ «ні пасивним інструментом того або іншого бога, ні іграшкою

Актуальні проблеми духовності:

зб. наук. праць / Рет.: Я.В. Шрамко

Вип. 11. - Кривий Piг, 2010, 124-131

ISSN $2076-7382$ 
космічних сил, ні рабом суспільних інституцій і навіть не жертвою створеної нею самою культури, а $є$ озброєним. . цінностями суб'єктом діяльності» [3], соціалізації і самореалізації, що здатний врегулювати свої відносини зі світом не лише відчуженої від неї сучасної культури, а й природи.

Отже, ціннісне світовідношення особистості, її духовність, немислимі поза практичним освоенням духовної культури суспільсства (релігії, філософії, науки, мистецтва) та функціонуючих у ньому політичних, моральних, естетичних та пізнавальних ідеалів. Смислові контури духовності, які найрельефніше зафіксовані в релігії, філософії, науці і мистецтві у ціннісному світовідношенні особистості проступають як потреба і здатність орієнтуватися на вищі загальнолюдські цінності істини, добра і краси у їх єдності. Останне виявляє себе певним духовно-культурним ідеалом, до якого особистість прагне у своєму духовнокультурному зростанні. Однак можливість його досягнення пов'язана не 3 простим спогляданням культурних цінностей, а з актуалізацією та розвитком культури власною творчою діяльністю, оскільки культура є універсальним способом самореалізації особистості, а предмети культури є результатом іï активної духовної творчості.

Самоцінність духовної культури для особистості полягає також у тому, що саме вона забезпечуе їй більш-менш вільну гру розуму, емоцій та почуттів, особистісних прагнень, є критерієм її суджень і оцінок соціальних цінностей і досягнень, критерієм оцінки власного розвитку та життєдіяльності. Культура завжди залишається скарбницею особистісного і соціального духовного досвіду, яка постійно збагачуеться досвідом багатьох індивідів і поколінь.

Усі реалії сучасної культури утворюють простір становлення і розвитку об'єктивних та суб'єктивних можливостей індивіда для творення себе, «творчого перетворення дійсності та формування ціннісних та цільових настанов» $[2$, с. 128$]$. «Людина засвоює культуру із соціального середовища, яке частково виховуе їі», «забезпечуе контакт між особою і соціальним середовищем» $[5$, с. 47] усіма можливими чинниками духовного впливу (релігія, мораль, мистецтво, філософія, освіта, навчання, виховання, наука, засоби інформації і комунікації). На жаль, зауважуе А. Моль, знання і цінності культури сучасна людська особистість бере собі на озброєння для орієнтапіії у світі скоріше під тиском стихійного впливу соціокультурного середовища ніж свідомого сприйняття за допомогою раціонально організованих та функціонуючих соціальних інституцій [5, с. 47]. Адже відомо, що чим вищий рівень усвідомлення соціальних відносин, ідеалів і смислів культури як 
способу ціннісно-світоглядної самореалізації та духовного оснащення особистості, тим суттєвіші її уяв.лення про життєву орієнтацію у світі, що зазвичай відображається системою етичних категорій: «бажане», «можливе», «належне».

Отже, функціонально соціокультурне середовище безпосередньо спрямовуе дії особистості у площину вибору реальних життевих можливостей за умови їх співвіднесеності 3 належним, існуючими ціннісними ідеалами і нормами. Соціальні ідеали і цінності культури як належне зорієнтовують особистість на чітке усвідомлення і свого темпорального призначення та місця у світі, яка відштовхуючись від теперішнього, того, що є актуальним сущим та опираючись на особистісний і соціально культурний минулий досвід формує уявлення про бажане майбутне. У цій же темпоральності, людина як біо-соціально-культурна істота безперервно розгортає у часі реальну суперечливість між повсякденною буденністю власного існування та загальнолюдським буттям культури, що по-особливому заломлюеться у особистісному світовідношенні, у самосвідомості особистості.

Загальнолюдський зміст культури відкривається індивідуальній свідомості, яка здатна піднестися над безпосередньою предметністю людського життя і діяльності та спрямувати життєву орієнтацію особистості не стільки у бік сущого, як вже відмічалось, скільки у бік належного і можливого при визначенні життєвої мети та одночасного устремління до реалізації вищих ідеалів у процесі втілення життевих цілей. У повсякденному житті людини останне має також суттеве значення, оскільки вона завжди виявляе свое сприйняття конкретної ситуації, обмеженої просторово-часовими і соціальними параметрами, «мовою реального життя» (Огієнко).

При цьому подібний духовний досвід особистості, грунтуючись на духовному досвіді людства, забезпечуе їй можливість визначатися 3 об'єктивними та суб'єктивними формами життєвої предметності, своїм життєвим світом, можливістю самореалізації та усвідомленням основи і перспектив подальшого існування і розвитку.

Соціокультурний контекст ціннісно-світоглядного становлення особистості можна розглядати на декількох рівнях відносин соціальнокультурного середовища та людини, однак найвпливовішими серед них, на наш погляд, $е$ рівень відносин особистості і суспільства, рівень розвитку відносин людського спілкування у процесі життєдіяльності та рівень розвитку відносин у сфері опредметнення особистістю власного життєвого досвіду і розпредметнення культурних цінностей.

Тобто, соціально-культурне середовище і особистість пов'язані між 
собою відносинами «взаемного відання і стримання, взаємної пасивності і дії [7, с. 70] у руслі яких культурні надбання людства, конкретного суспільства постають надбанням особистості, «вектором» і «полем» їі розвитку. Вже вивчення спілкування і діяльності дитини у сім’і і дитячому колективі допомагае певним чином оцінити її світовідношення, зміст її світоглядної свідомості. Як зазначалось нами раніше, інформація від соціально-культурного середовища на перших етапах формування світоглядної свідомості дитини передаеться в основному у двох формах: традиційній та речово-предметній [4, с. 57-58]. Недоліком першої є те, що у світогляді дитини можуть посідати значне місце певні культурні стереотипи, які не рідко надають йому конформізму та консерватизму.

Але з іншого боку традиції «конденсують» соціальний і культурний досвід людей, що належать до єдиного культурного середовища і часу та «акумулюють» специфічні умови для проланганції даного досвіду у майбутньому. А тому відкидати таку складову людського світовідношення як традиційність не варто, оскільки традиції- це певний спосіб залучення особистості до соціального досвіду багатьох поколінь, це найбільш природній (особливо для дитини) спосіб актуалізації світовідношення індивіда.

Речово-предметна форма передачі соціокультурної інформації від середовища до особистості вирізняється тим, що їі носіями $є$ предмети 3 якими людина постійно виконуе якісь дії і які ніби то завдають певні інваріанти поведінки і вчинків особистості. Отже виявляється, що соціально-культурна зумовленість притаманна уже світовідношенню дитини. Воно детерміноване рівнем культури перш за все такого середовища як сім'я, рівнем сімейної і побутової культури, моральнопсихологічного клімату, близького родинного оточення та ін. Подальший процес формування світо відношення особистості пов'язаний 3 освоєнням нею духовної культури іншими способами і каналами, про що йтиметься нижче. Однак при цьому усі здобутки власного досвіду, різних форм соціалізації і культурації повинні бути узгодженими між собою та поступово перетворюватися у ціннісні переконання особистості. Саме власний життєвий досвід особистості серед усіх джерел формування їі світовідношення посідає провідне місце. Саме він є найбільш «чутливим барометром» до соціокультурних змін, до змін у всіх сферах людського життя, що безумовно викликае необхідність корегування власного світовідношення.

Оскільки будь-яке світовідношення передусім $є$ відображенням загальності людської практичної діяльності (чи то матеріальної, чи то 
духовної), то індивідуальне, особистісне світовідношення є перш за все усвідомленням своеї приналежності до людськості, до світу певних соціальних відносин і людських комунікацій, до світу певної культури. Тобто, кожний індивід Знаходить соціальний і предметно-культурний світ як передумову власної життедіяльності, але при цьому він реально стикається з цією передумовою у формі значущих для нього мотивів і подій власного життя, у ході усвідомлення і реалізації яких особа актуалізуе відповідну сукупність форм соціально-практичної діяльності, а саме ті форми, які є особистісною життєвою необхідністю.

Подібна сукупність актуальностей особистісного світовідношення i утворюе життевий світ людини, а самореалізація індивіда у предметній діяльності набуває ознак всезагального культурно-історичного смислу - як творення соціальності та одночасне творення самого себе як суб'єкта культурно-історичної дії. Культура, таким чином, як предметність «другої природи» $\varepsilon$ предметним результатом реалізації творчого потенціалу особистості, як суб'єкта культурно-історичної дії. А щоб сощіокультурний універсум відчув на собі таку креативність людини, її дії повинні бути у свою чергу наслідком усвідомлення цінностей актуальної системи культури. Саме останне актуалізуе і власний розвиток особистості, вдосконалення форм реалізації свого життєвого досвіду, своеї суб'єктивності, задатків, здібностей, свого світогляду, свідомості і самосвідомості, тобто усього того, що буде позитивно впливати на соціокультурне за змістом та екзистенціальне за способом буття людини, на еволюцію її світовідношення.

Не секрет, що рано чи пізно людина постане перед необхідністю усвідомлення того, чим вона буде керуватися у будь-якій життєвій ситуації - чим то, що знаходиться за межами природного і соціального світу - вищими цінностями істини, добра і краси, чи підпорядкуе себе «голосу природи», голосу власних пристрастей та всіляких, особливо надуманих, бажань. В еволюції світовідношення проглядається мобільність особистості, вміння змінювати стиль дій, поведінки, чітке і вчасне реагування на соціокультурні новації, автором яких може бути сама особистість.

Іншими словами, людські бажання будуть істинно людськими за умови їх культурного облаштування, культурної оформленості. Тому зрозуміло, що жодна людина не може існувати поза культурою, однак форми такого буття бувають різноманітними (елітна, субкультура, контркультура, монокультура, поп-культура, професійна культура i ін.). Але ж і культура не може існувати у відірваності від людини, оскільки саме вона формулюе смислову антитезу життєвому хаосу, 
плутанині, життевій невпорядкованості.

Отже, «реально-оріентуючі» та «належно-орієнтуючі» [1, с. 190] інтенції культури забезпечують можливість, зміст і функціонування світовідношення особистості. Засвоюючи цінності і смисли культури як единий людиномірний спосіб буття, що дозволяе людській особистості виявити свою людськість і людяність, свої життєві сенси, особа тим самим відшукуе особистісний аспект культури, перетворюючи ї̈ універсальний зміст в індивідуальний, у систему індивідуальних цінностей і ідеалів, знаходячись при цьому з нею (культурою) у двобічному прямому та зворотньому креативному зв'язку.

Таким чином, розуміння людини як біо-соціо-культурної істоти $e$ методологічною основою подолання існуючих уявлень про одвічний конфлікт людської натури і культури та основою формування більш зрілого світовідношення особистості, яке і стане відповідною формою регуляції її існування - як саморегуляції і самовизначення у простоpi культури. 3 іншого боку, таке світовідношення людини висвітлюе механізм «переведення» нею предметного, соціального та культурного світів у власний світ, як особистісну сферу внутрішнього буття, масштаб і зміст якого стають основою критичного погляду особистості на себе, основою особистісної самооцінки, мірилом якої є совість та її моральні предикати: чиста-нечиста совість, муки совісті і т. ін.

За умов надмірної «мозаїчності» сучасної культури, особливо інформаційно-раціонального спрямування, яка звалюється на кожного індивіда як злива, дуже важливо сприяти виробленню рефлективних здатностей особистості, точніше кажучи, формуванню індивідуальної рефлексивної культури, яка і буде втіленням єднання креативності світосприймання та ціннісної розважливості. Крім того, саме людське рефлексування забезпечуе функціонування ще одного каналу переводу соціокультурного змісту у світовідношення особистості-вербального каналу, який численними повідомленнями про різні життєві ситуації у формі мови, раціонального знання, символів і смислів підносить світоглядну свідомість особистості до рівня всезагальної значимості та адекватної цим значимостям її орієнтації у світі.

«Берегинею» розуміння вище згаданого поєднання «була i залишається філософія» [6, с. 424], а ми б додали - усього соціально-гуманітарного пізнання і знання, загально визнаних та не зовсім, культур освіти, навчання та виховання, як найбільш ранніх сфер соціокультурного впливу на особистість та сфер її залучення до цінностей культури. Результатом такого залучення і будуть «людина-в-культурі» та «людина культури», відмінність між якими полягає у тому, що перша- 
завжди говорить від чужого імені, від імені культури і ніколи не відчуває себе 111 «автором», творцем культурних форм. Друга ж-ніколи не сприймає культуру як засіб досягнення своїх вітальних життєвих потреб. Для неї культура - не передумова життя, а саме життя, бо саме у культурі вона зреалізовуе свою онтологічну потребу - потребу бути людиною, бути особистістю зі всіма сокровенними порухами своєї душі, зі своєю індивідуальною смисловою явленістю світові. I саме тому такі одвічні цінності як істина, добро, краса, життя є безумовними цінностями для кожної людини і у той же час, що таке добро і зло у кожній конкретній життевій ситуації кожна людина вирішує на власний розсуд, демонструючи при цьому свою обізнаність, освіченість, ерудованість, вихованість, акуратність, толерантність, гуманність, тобто складові своєї особистісної культури.

У такій світоглядній орієнтації особистості роль «першої скрипки» відіграють неминущі цінності духовної культури, що містять у собі наука, мораль, релігія, філософія, мистецтво. Тому докорінне їх завдання сьогодні і полягає у тому, щоб осмислити і обгрунтувати всю складність світовідношення сучасної людини як біо-соціо-культурної істоти, істоти яка творить культуру, а культура навчае людину бути і завжди залишатись людиною. Але виконання цього завдання можливе за умови поєднання зусиль усіх форм духовно-практичного опанування світу людиною, які зуміють актуалізувати найважливіші життеві проблеми людської особистості та ввести їх у простір культури. Тобто, йдеться про духовно-ціннісну репрезентацію такої практичної загальнолюдської життевої ситуації, у якій ціннісно-світоглядні новації постають умовою виживання людини, людства, особистості. Однак варто при цьому зауважити, що стрімкість змін життевих ситуацій людини бувае такою, що світоглядні новації не «встигають» за ними, тим не менше вони обов'язково стануть реальністю адекватною тим або іншим соціокультурним змінам.

Нинішня ж соціально-культурна ситуація в Україні вимагає цілеспрямовано і послідовно формувати, особливо у молодого покоління, що лише входить у самостійне життя, таке світовідношення, яке було б вільним від надмірного верхоглядства, позірності, хизування, усіляких комплексів (включаючи національну і громадянську меншовартість) та схильним до усвідомлення діалогічних відносин зі світом природи, суспільства, культури, усвідомлення необхідності гармонізації відносин між власною природою і духовністю, «між вродженим... та надбаним, успадкованим від родини та вихованим сучасниками, індивідуальним та соціальним» [3]. 


\section{1 Бібліографія}

[1] Диалектика деятельности и культура / Отв. ред. В.Г. Табачковский, А.И. Яценко. - К.: Наукова думка, 1983.

[2] Жизненный путь личности. Вопросы теории и методологии социально-психологических исследований. - К.: Наукова думка, 1987.

[3] Каган М.С. Человек как проблема современной философии. - Peжим доступу: http://anthropology.ru/ru/texts/kagan/man.html

[4] Макутон П.Я., Хорольська Т.А. Світогляд особистості у соціокультурному контексті // Проблеми філософії. Наук. збірн. - K.: Либідь, 1991.

[5] Моль А. Социодинамика культуры. - М.: Прогресс, 1973.

[6] Табачковський В.Г. Полісутнісне һото: філософсько-мистецька думка в пошуках «неевклідової рефлективності». - К.: ПАРАПАН, 2005.

[7] Фuxme И. О назначении ученого. - М., 1935.

Надійшла до редакчй 24 травня 2010 p. 